\title{
Housing first: How Finland is ending homelessness
}

Written by: Juha Kaakinen, CEO, Y-Foundation

Last update: 2 March 2020

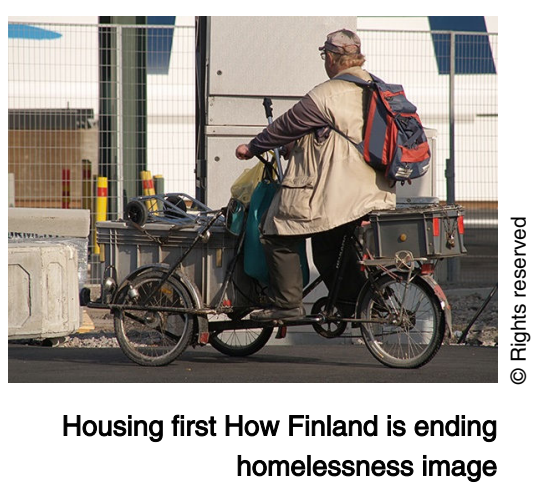

It was seven years ago when Arvo (not his real name) first walked into this building. Back then, it was a hostel for homeless men run by the Salvation Army and had a certain reputation. Arvo can still remember opening the door to his dormitory. There were three men sitting on their beds, their faces sullen and melancholy. This would be his new home for a while.

Arvo had been down and out already for a while, staying with some of his few remaining friends and occasionally hanging around in public places, stations and staircases. His ex-wife and their daughter were now just a fading memory. Staying at the hostel was better than nothing, but hardly more than that.

Today, Arvo is opening another door-except this time it is to a rental flat of his own. It's still the same building but it has been converted into independent rental flats, completely renovated and new. The building is well-located in the city. And while the flat is not big, it has everything Arvo needs, like kitchen facilities and bathroom, and an affordable rent. When Arvo moved in he barely slept the first few nights. He kept expecting someone to come in without knocking on the door. But no one came, it is now his home, his kingdom.

Since moving in, Arvo seldom drinks anymore-he doesn't want to run the chance of losing his home. Tomorrow is a big day: he has a job interview. Maybe this time he'll be in luck on the work front too. He feels hopeful, there are reasons to live, and still a future for him. 
Arvo's is just one of many stories at Alppikatu 25, a supported housing unit in Helsinki, which now has 81 rental flats for long-term, homeless people. Built in 1936 , the building was completely renovated in 2012 at a cost of $€ 9.2 \mathrm{M}$, financed by a 50\% investment grant from the Housing Finance and Development Centre of Finland. It provides independent apartments, common facilities and on-site support for tenants.

Alppikatu 25 is a kind of a flagship for Finland's new policy to end homelessness. It illustrates the aspirations and concrete measures of the National Programme to End Long-term Homelessness (PAAVO), which was started in 2008. One of PAAVO's cornerstones is the strategy of replacing temporary accommodation with permanent housing based on rental contracts. This has fundamentally changed the structure of services and housing solutions available for homeless people. In our thinking, people living in temporary shelters and hostels are still homeless. Only permanent housing can provide a safe, sustainable solution to homelessness and a foundation for a decent life.

The change in the service structure has been quite dramatic. In 2008, there were almost 600 beds in shelters and hostels in Helsinki. Now there is only one permanent service centre for emergency accommodation with 52 beds (in winter time extra temporary accommodation is provided if needed).

An important lesson we have learned during the last 10 years is that you can't have Housing First without actually having housing first. This means providing independent, permanent rental flats unconditionally and with support if it is needed and wanted. It is also important to provide different housing alternatives. Most homeless people prefer an independent flat in scattered housing. Others prefer living in their own rental flats in a more communal structure with in-house support. This may be because they fear the isolation and loneliness of scattered housing, or their support needs are intensive.

In recent years, Finland has been one of the few countries where homelessness has decreased. The Finnish success has been explained by this national strategy, targeting the most vulnerable, long-term homeless people. Even more important has been the way in which PAAVO was nationally implemented. Co-ordinated by the Ministry of Environment, these programmes have been carried out in wide partnerships between ministries, cities and civil society groups. The work is carried out together according to mutual agreements and plans with shared financial responsibility of the state and cities.

In 10 years, over 7,290 homes have been provided for homeless people. All possible channels have been used: scattered flats bought on the private market, rental flats from social housing and new supported housing flats built or renovated in housing units. The role of affordable social housing has been crucial as this housing stock is also the most important structural measure of homelessness prevention. 
In 1987, there were 1,370 homeless families and 17,110 single homeless persons in Finland. Compare that to the latest tally (2017): 214 homeless families and 6,615 single homeless persons of whom 5,528 are living temporarily with friends or relatives. We can't be sure that the numbers will continue to go down, but we know that it is possible with continuous, determined work.

The Finnish example shows that homelessness is not a law of nature. It is possible to decrease and even end homelessness. It is a question of recognising housing as a basic human right and having a determined government who will lead the way.

@OOECD Observer March 2019

\section{References}

$\underline{\text { http://dx.doi.org/ }}$

Learn more about the Y-Foundation at https://ysaatio.fi/en/housing-firstfinland https://ysaatio.fi/en/housing-first-finland

This article is part of a series celebrating Finland's 50th anniversary as a member country of the OECD: www.oecdobserver.org/finland50oecd www.oecdobserver.org/finland50oecd 